\title{
Impact of Crude Oil Storage Tank Emissions and Gas Flaring on Air/Rainwater Quality and Weather Conditions in Bonny Industrial Island, Nigeria
}

\author{
Vincent Ezikornwor Weli, Nsikak I. Itam \\ Department of Geography and Environmental Management, Faculty of Social Sciences, University of Port \\ Harcourt, Port Harcourt, Nigeria \\ Email:welivinezi@yahoo.com
}

Received 8 March 2016; accepted 10 June 2016; published 13 June 2016

Copyright (C) 2016 by authors and Scientific Research Publishing Inc.

This work is licensed under the Creative Commons Attribution International License (CC BY). http://creativecommons.org/licenses/by/4.0/

(c) (i) Open Access

\section{Abstract}

This study investigated the effects of gaseous emissions from crude storage tank and gas flaring on air and rainwater quality in Bonny Industrial Island. Ambient air quality parameters, rainwater and weather parameters were collected at $60 \mathrm{~m}, 80 \mathrm{~m}, 100 \mathrm{~m}, 200 \mathrm{~m}$ and control plot for 4 weeks at the Bonny. Rainwater parameters were investigated using standard laboratory tests. Data analyses were done using Analysis of variance, pairwise t-test and Pearson's correlation statistical tools. Results show that emission rates, volatile organic compound (VOC) noise and flare temperature decreased with increasing distance from flare points and crude oil storage tanks. Findings further revealed the emission rates varied significantly with distance away from the gas flaring point $(F=6.196 ; p=0.004)$. The mean concentration of pollutants between gas flare site and crude oil storage tank showed that CO $(0.02 \pm 0.001-0.002 \pm 0.001)$, SPM $(0.011 \pm 0.001-0.01 \pm 0.001)$, VOC $(0.005 \pm 0.001-0.01 \pm 0.001)$ and $\mathrm{NO}_{2}(0.04 \pm 0.001-0.005 \pm 0.000)$ had significant variations $(p>0.05)$ with $\mathrm{CO}, \mathrm{O}_{3}$ and $\mathrm{NO}_{2}$ having higher concentrations at the gas flare site while SPM, and VOC were higher around the crude oil storage tank site. Wind turbulence was higher around the gas flaring point (4.93 TKE) than the crude oil storage tank (4.55 TKE). Similarly, there was significant variation in the sun radiation, precipitation, and wind speed caused by gas flaring $(1582.25$ $\left.\mathrm{w} / \mathrm{m}^{2}, 436.25 \mathrm{~mm}, 0.53 \mathrm{~m} / \mathrm{s}\right)$ and crude oil storage tank $\left(1536.25 \mathrm{w} / \mathrm{m}^{2}, 3.91 .41 \mathrm{~mm}, 0.51 \mathrm{~m} / \mathrm{s}\right)$. There were also significant variations in flared temperature $(F=22.144 ; p=0.001) ; \mathrm{NO}_{2}(F=8.250$; $p=0.001), C O(F=6.000 ; p=0.004)$ and $\operatorname{VOC}(F=5.574 ; p=0.006)$ with distance from the gas flaring point. The variation in the rainwater parameters with distance from the gas flaring indicated significant variations in $\mathrm{pH}(\mathrm{F}=5.594 ; \mathrm{p}=0.006)$. The study showed that the concentration of VOC and particulates were high in the supposedly control area which is perceived to be safe for human habitation. Significant variations exist in emission rate $(p=0.015)$, flare temperature $(p=$ 
$0.001), \mathrm{NO}_{2}(\mathrm{p}=0.003)$, VOC $(\mathrm{p}=0.001)$, noise $(\mathrm{p}=0.041)$, hydrogen carbonate $(\mathrm{p}=0.037)$ and chromium ( $p=0.032)$ between the gas flaring and crude oil storage tank. Regular monitoring is advocated to mitigate the harmful effects of the pollutants.

\section{Keywords}

Gas Flaring, Crude Oil Tank, Air Quality, Rainwater, Meteorological Parameters

\section{Introduction}

Emissions from oil prospecting platforms and its environmental problems have continued to attract the attention of air pollution meteorologist and environmental experts amongst others [1]-[4]. Gas flaring in the developing country such as Nigeria looks inevitable due to the absence of an efficient regulatory framework, inaccessibility to domestic and international markets and limited finances. [5]-[7] opined that gas flaring is practiced in Nigeria because it is cheap and there is lack of the technology needed to harvest or re-inject gas. Meanwhile, gaseous emission and flaring into atmosphere started since the inception of petroleum exploration in the Niger Delta in 1956 [8]. According to [8] and [6], a total estimated amount of 160 Billion Cubic Meters (BCM) of gas was flared, of which Nigeria flared over $14 \%$, ranking second only to Russia among the top twenty gas flaring countries in 2004. A typical gas flare in Nigerian oilfield is usually located at ground level, and is surrounded by thick vegetation and farmlands, with the village's huts and human inhabitants located from about 20 - 30 metres from the heat source or flare [9]. Meanwhile, liquefied natural gas (LNG) company operations generally have both positive and negative effects on the environment and society as they provide an important commodity for domestic and industrial use [10]. Flaring of associated gas from oil and gas exploration and production operations has several consequences on the environment. Studies have suggested associations between gas flaring and health problems in the communities [11] [12] and between gas flaring and poor agricultural yields and farm income [4] [13]. According to [14], the assessment of the polycyclic aromatic hydrocarbons (PAHs) compound ratios, phenanthrene/anthracene and fluoranthene/pyrene, suggested that predominant present of PAHs of pyrogenic sources in surface soils was an indication that oil leakage and/or gas flaring contributes to soil contamination. [7] found that the residents in Niger Delta perceived gas flaring as hazardous to health, environment, and general well-being of the oil-producing host communities. [12] showed that gas flaring had effects on corrosion of zinc roofs in the Niger Delta. Studies show that gas flaring significantly affects not only the microclimate but also the soil physio-chemical properties of the flare sites [15] [16].

From the available literature, it is obvious that air pollution problems associated with gas flares is not new, however, the combined effects of both flare gases and importantly emissions from crude oil storage tanks which are not visible especially as they affect ambient air and rainwater quality has not been given due attention in the literature. This is the gap which this paper intends to provide. To achieve this, the following conceptual questions are posed; what is the difference in the effects of gas flaring and gas emission from storage tank on rainwater? What is the difference in the effects of gas flaring and gas emission storage tank on air quality? Is there any difference in the meteorological parameters (air temperature, wind speed, atmospheric pressure, relative humidity, precipitation and sun radiation) with distance away from gas flaring point and crude oil storage tank in the study area?

\section{The Study Area}

The study was carried out in Bonny Island, Bonny LGA, Rivers State. The study area was located between latitudes $4^{\circ} 458^{\prime} \mathrm{N}$ and $4^{\circ} 45^{\prime} \mathrm{N}$, and longitudes between $7^{\circ} 13^{\prime} \mathrm{E}$ and $7^{\circ} 21^{\prime} \mathrm{E}$ (Figure 1). It contains the Bonny Terminal facility with coordinate location. The Bonny Island axis of the Niger Delta, Nigeria, is one of the most industrialized belts of Nigeria. Among the significant industries in the locality are the Bonny Oil and Gas Terminal. It comprises of crude and gas receiving facilities; treatment facilities; crude storage facilities; crude and gas export facilities and supporting facilities. The plant is one of Nigeria's critical assets from which substantial amount of the nation's crude oil export is affected. Bonny falls within the OML 11 oil block, which belongs to the Shell Petroleum Development Company (SPDC). The present Terminal occupies an area of 1,209,015 $\mathrm{m}^{2}$ and has a 


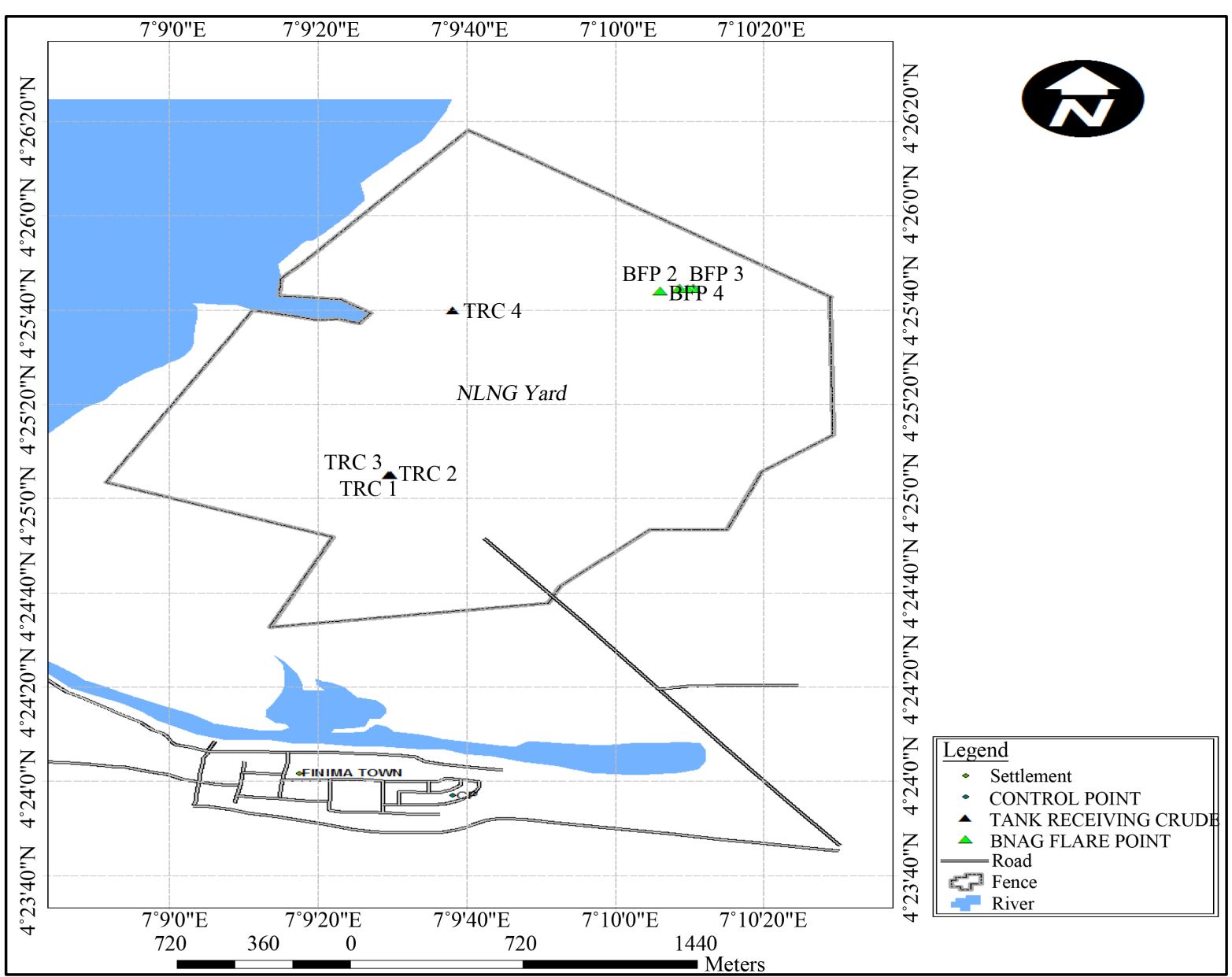

Figure 1. Study area showing the sample locations.

design storage capacity of 7.5 million barrels [17]. The various communities that are found within the study area include: Old Finima, New Finima, Iwoma, Agaja, Edoko-Dogokiri, Ayamabo and Azumba-Jumbo etc. The climatic condition within the area of study is dominated by two climatic seasons which are dry and wet seasons. In addition, because of its closeness to the equator, the area experiences high sunshine and high cloud cover for most part of the year. Indeed, the climate can be described as a typical tropical climate with high temperature and rainfall throughout the year. It must be noted however, that there is no marked dry season in the area because there is hardly any month without rainfall. The drainage system in the study area is very poor and comprises of dense network of rivers, creeks, streams, lakes and lagoons among which include Bonny River. The rivers and creeks flow into the Atlantic Ocean. Soils in Bonny are a mixture of rock particles loosened by weathering and made up of mineral inorganic particles (such as sand silt and clay) and organic matter (humus) derived from decomposed remains of plants and animals. The soils of this eco-region are all of fluviatile origin, except for the Coastal Barrier Islands that consist of marine sand overlain with an organic surface layer. The continuous movement of the delta's creeks has resulted in a mosaic of soil types. Remnants of old levees consist mostly of water permeable sand and loam. The soil of the depressions behind them (back swamps) consists mostly of waterlogged heavy clay covered by peat, while higher lying sections consist of silty loam and clay.

\section{Conceptual Issues and Methods of Data Collection}

This study adopted the Concept of Air Pollutants Spread in explaining the effects of emissions from crude oil storage tanks and gas flaring on ambient air and rain water quality. According to [16], when a plume is discharged from an elevated stack, it will spread vertically until its lower edge reaches the ground. If a strong inversion layer is located at some height above the stack, then the plume will have difficulty expanding vertically 
and will effectively be "trapped" between the inversion and the ground. Plume reflection will occur in this case at both the ground and the inversion layer. The concept of plume reflection is being guided by Eulerian grid modeling describing pollutant spread over urban areas which is restricted to episodic conditions, and focused primarily on Ozone $\left(\mathrm{O}_{3}\right)$ [17] and Lagrangian modeling explaining the pollutant spread over large distances and longer time-periods. The later formed the focus of the study. Upon the above premise, the Concept of Air Pollutants Spread is vital to this study because it helps us to understand the movement of air pollutants (emissions) and its effect on the air and rainfall water quality in Bonny industrial island of Rivers State.

The sample sites were purposively selected to assess the concentration; nature of gases emitted and flared; location of crude storage tank and gas flare point as well as their orientation. Different samples at various proximities $(60 \mathrm{~m}, 80 \mathrm{~m}, 100 \mathrm{~m}$ and $200 \mathrm{~m})$ from the crude storage tank and gas flare location were taken and measurements and experimentations carried out according to standards for both gases and rainwater. In all, nine sampling points were considered. These include eight points from the primary emission sources and one control point. At each sampling point, ambient air quality and rainwater quality were sampled. Rainwater analysis was done for the following parameters: $\mathrm{pH}$, Conductivity, SOx (Sulphate), NOx (Nitrate), Hydrogen carbonate $\left(\mathrm{HCO}_{3}\right)$, Total Hydrocarbon (THC), Copper $(\mathrm{Cu})$ and Chromium (Cr). $\mathrm{pH}$ was measured in-situ using a Beckman Electrode $\mathrm{pH}$ meter. Electrical conductivity was determined using a Jenway PCM1 portable conductivity meter. The total hydrocarbon compound in rainwater samples was carried out using Agilent 6890N Gas Chromatograph-Flame Ionization Detector (GC-FID) instrument. Heavy metals ( $\mathrm{Cu}$ and $\mathrm{Cr}$ ) were analyzed using atomic absorption spectrophometer (AAS) as described in APHA 3111B and ASTM D3651. This involved direct aspiration of the sample into an air/acetylene or nitrous oxide/acetylene flame generated by a hollow cathode lamp at a specific wavelength peculiar only to the metal programmed for analysis. For every metal investigated, standards and blanks were prepared and used for calibration before samples were aspirated. Concentrations at specific absorbance displayed on the data system monitor for printing. Limit of detection is $<0.001 \mathrm{mg} / \mathrm{l}$. $\mathrm{NO}_{2}, \mathrm{SO}_{2}$ and $\mathrm{HCO}_{3}$ were analyzed by ion chromatography (Metrohm 761 Compact IC with suppressed module, equipped with an anion-separator column (Dual 2). Sampling was performed weekly for 4-week period. All selected sites in the Bonny Terminal were old but still in production. Records indicate that the selected sites have been flared for 52 years. The selection of such old sites was based on the premise that the cumulative effects of waste gas emissions and flares are a better representation of speculated air quality-flare site relationship.

Descriptive analysis was used to explain mean values of air quality parameters, rainwater parameters and meteorological parameters with respect to distance in the study area. Analysis of variance (ANOVA) was used to analyze the conceptual question formulated for this study. Pearson's Product Moment Correlation (PPMC) statistics was employed in testing for the significance of the relationships between the weather parameters and air/ rainwater quality parameters.

\section{Results and Discussion of Findings}

\subsection{Comparative Variation in the Effects of Gas Flaring and Crude Oil Storage Tank on Air and Rainwater Quality}

In the comparative analysis between the effects of gas flaring and crude oil storage tank on air quality (Table 1), result showed that the mean emission rate was 10,225 scf/hr and 10,149.00 scf/hr around gas flare point and the crude oil storage tank respectively. The t-test shows significant difference in the emission rate between gas flaring and crude oil storage tank in Bonny. The mean flare temperature was $28.30^{\circ} \mathrm{C}$ around gas flaring and $27.80^{\circ} \mathrm{C}$ around the crude oil storage tank. Significant variation occurred in the flare temperature between gas flaring and crude oil storage tank. The mean $\mathrm{SO}_{2}, \mathrm{CO}, \mathrm{H}_{2} \mathrm{~S}$ and $\mathrm{O}_{3}$ around gas flaring point and crude oil storage tank were the same. Except $\mathrm{CO}$ and $\mathrm{O}_{3}$ recording $0.002 \mathrm{ppm}$ and $0.01 \mathrm{pm}$ respectively; $\mathrm{SO}_{2}$ and $\mathrm{H}_{2} \mathrm{~S}$ recorded no value. The mean $\mathrm{NO}_{2}$ around gas flaring point and crude oil storage tank was $0.004 \mathrm{ppm}$ and $0.0005 \mathrm{ppm}$. Significant variation existed in the $\mathrm{NO}_{2}$ between the gas flaring and crude oil storage tank. The mean SPM was $0.011 \mathrm{ppm}$ and $0.01 \mathrm{ppm}$ in gas flaring point and crude oil storage tank respectively but there was no significant variation in the SPM. The mean VOC was $0.005 \mathrm{ppm}$ around the gas flaring point and $0.04 \mathrm{ppm}$ around the crude oil storage tank. This shows that the VOC was higher in the crude oil storage tank than the gas flaring point. The mean noise level around the gas flaring was $67.45 \mathrm{db}$ while around the crude oil storage tank; the noise level was $69.03 \mathrm{db}$. This shows that the noise level was higher around the crude oil storage tank with significant variation. The pair-wise analysis of the effect of flare site and crude oil storage tanks on air quality is 
Table 1. T-test analysis between air quality around the gas flaring point and crude oil storage tank in bonny.

\begin{tabular}{cccc}
\hline Air Quality & Gas Flaring & Crude Oil Tank & T-test (Pairwise) Significance (p value) \\
\hline Emission Rate $(\mathrm{scf} / \mathrm{hr})$ & $10,225.05 \pm 36.9$ & $10,149.00 \pm 26.65$ & $0.015^{*}$ \\
Flare Temperature $\left({ }^{\circ} \mathrm{C}\right)$ & $28.30 \pm 0.18$ & $27.80 \pm 0.09$ & $0.001^{*}$ \\
$\mathrm{SO}_{2}(\mathrm{ppm})$ & $0.00 \pm 0.00$ & $0.00 \pm 0.00$ & Not Applicable $^{*}$ \\
$\mathrm{NO}_{2}(\mathrm{ppm})$ & $0.004 \pm 0.001$ & $0.0005 \pm 0.00$ & $0.003^{*}$ \\
$\mathrm{CO}(\mathrm{ppm})$ & $0.002 \pm 0.001$ & $0.002 \pm 0.001$ & Not Applicable \\
$\mathrm{SPM}(\mathrm{ppm})$ & $0.011 \pm 0.001$ & $0.01 \pm 0.001$ & 0.781 (NS) \\
$\mathrm{VOC}(\mathrm{ppm})$ & $0.005 \pm 0.001$ & $0.04 \pm 0.006$ & $0.001^{*}$ \\
$\mathrm{H} 2 \mathrm{~S}(\mathrm{ppm})$ & $0.00 \pm 0.00$ & $0.00 \pm 0.00$ & Not Applicable \\
$\mathrm{O}_{3}(\mathrm{ppm})$ & $0.01 \pm 0.00$ & $0.01 \pm 0.00$ & Not Applicable \\
$\mathrm{Noise}(\mathrm{db})$ & $67.45 \pm 1.74$ & $69.03 \pm 1.61$ & $0.041^{*}$ \\
\hline
\end{tabular}

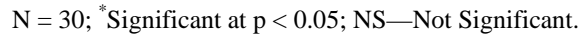

shown Table 1.

Similarly, findings revealed that comparatively, the mean $\mathrm{pH}$ of rainwater around gas flaring was 6.66 while it was 6.53 around the crude oil storage tank (Table 2). The analysis on the pH shows that rainwater in both sites was weakly acidic but it was more acidic around the crude oil storage tank. The mean conductivity level of rainwater around the gas flaring point and crude oil storage tank was $35.08 \mu \mathrm{s} / \mathrm{cm}$ and $33.18 \mu \mathrm{s} / \mathrm{cm}$ respectively. Furthermore, there was no difference in the mean total hydrocarbon and copper around the gas flaring point and crude oil storage tank in the study area. However, the mean nitrate was $0.56 \mathrm{mg} / \mathrm{l}$ around the gas flaring while it was $0.68 \mathrm{mg} / \mathrm{l}$ around the crude oil storage tank. In addition, the mean sulphate was $1.16 \mathrm{mg} / \mathrm{l}$ and $1.32 \mathrm{mg} / \mathrm{l}$ around the gas flaring point and crude oil storage tank respectively. Hydrogen Carbonate was higher around the gas flaring point than the crude oil storage tank and significant variation was noted in the concentration of hydrogen carbonate in the rainwater between gas flaring and crude oil storage tank. There was significant variation in the chromium between gas flaring and crude oil storage tank. The chromium in the gas flaring and crude oil storage tank was $0.0012 \mathrm{mg} / \mathrm{l}$ and $0.21 \mathrm{mg} / \mathrm{l}$ respectively. The elevated concentration of $\mathrm{t} \mathrm{NO}_{2}, \mathrm{VOC}$ and $\mathrm{O}_{3}$ were found to have been affected by gas flaring and emissions from the crude oil storage tank. These findings are supported by the works of [18] which observed that gases flared contains gaseous pollutants like $\mathrm{CO}_{2}$, $\mathrm{CO}$, $\mathrm{NO}, \mathrm{NO}_{2}$, and $\mathrm{SO}_{2}$. Also the study conducted by of [19] reported that the flares associated with gas flaring give rise to atmospheric contaminants which include oxides of Nitrogen, Carbon and Sulphur $\left(\mathrm{NO}_{2}, \mathrm{CO}_{2}, \mathrm{CO}_{2} \mathrm{SO}_{2}\right)$, particulate matter, hydrocarbons and ash, photochemical oxidants, and hydrogen sulphide $\left(\mathrm{H}_{2} \mathrm{~S}\right)$.

\subsection{Comparative Variation on the Effects of Gas Flaring and Crude Oil Tank Emissions on Weather Characteristics}

The comparative variation in the effects of gas flaring and crude oil storage tank on weather parameters is shown in Table 3. The mean air temperature was $27.99^{\circ} \mathrm{C}$ around gas flaring while it was $28.85^{\circ} \mathrm{C}$ around the crude oil storage tank in Bonny. There was significant variation in the air temperature between gas flaring and crude oil storage tank. The mean windspeed was $0.53 \mathrm{~m} / \mathrm{s}$ around gas flaring while the mean windspeed around crude oil storage tank was $0.51 \mathrm{~m} / \mathrm{s}$. The mean atmospheric pressure was slightly different between gas flaring (14.71 psi) and crude oil storage tank (14.69 psi). The mean relative humidity was $85.74 \%$ around the gas flaring point while it was $82.01 \%$ around the crude oil storage tank. There was a significant variation in the relative humidity between gas flaring and crude oil storage tank. Wind turbulence was higher around the gas flaring point (4.93 TKE) than the crude oil storage tank (4.55 TKE). Furthermore, the mean precipitation around gas flaring point and crude oil storage tank was $436.25 \mathrm{~mm}$ and $391.42 \mathrm{~mm}$ respectively. Significant variation existed in the volume of precipitation between gas flaring and crude oil storage tank. The mean sun radiation around gas flaring and crude oil storage tank was $1582.25 \mathrm{w} / \mathrm{m}^{2}$ and $1536.25 \mathrm{w} / \mathrm{m}^{2}$ respectively. There was significant variation in the sun radiation caused by gas flaring and crude oil storage tank. 
Table 2. T-test of rainwater quality around the gas flaring point and crude oil storage tank.

\begin{tabular}{cccc}
\hline Rainwater Parameters & Gas Flaring & Crude Oil Tank & T-test (Pairwise) Significance (p Value) \\
\hline $\mathrm{pH}$ & $6.66 \pm 0.12$ & $6.53 \pm 0.11$ & 0.157 \\
Conductivity $(\mu \mathrm{s} / \mathrm{cm})$ & $35.08 \pm 3.53$ & $33.18 \pm 3.32$ & 0.666 \\
Total Hydrocarbon $(\mathrm{mg} / \mathrm{l})$ & $0.01 \pm 0.00$ & $0.01 \pm 0.00$ & Not Applicable \\
Nitrate $(\mathrm{mg} / \mathrm{l})$ & $0.56 \pm 0.09$ & $0.68 \pm 0.08$ & 0.303 \\
Sulphate $(\mathrm{mg} / \mathrm{l})$ & $1.16 \pm 0.11$ & $1.32 \pm 0.14$ & 0.093 \\
Hydrogen Carbonate $(\mathrm{mg} / \mathrm{l})$ & $0.0235 \pm 0.002$ & $0.018 \pm 0.002$ & $0.037^{*}$ \\
Copper $(\mathrm{mg} / \mathrm{l})$ & $0.001 \pm 0.00$ & $0.001 \pm 0.00$ & Not Applicable $^{*}$ \\
Chromium $(\mathrm{mg} / \mathrm{l})$ & $0.0012 \pm 0.00$ & $0.21 \pm 0.09$ & $0.032^{*}$ \\
\hline
\end{tabular}

$\mathrm{N}=20$; ${ }^{*}$ Significant at $\mathrm{p}<0.05$.

Table 3. Weather parameters around the gas flaring point and crude oil storage tank.

\begin{tabular}{cccc}
\hline Weather Parameter & Gas Flaring & Crude Oil Tank & T-test (Pairwise) Significance (p value) \\
\hline Air Temperature $\left({ }^{\circ} \mathrm{C}\right)$ & $27.99 \pm 0.31$ & $28.85 \pm 0.24$ & $0.007^{*}$ \\
Wind Speed $(\mathrm{m} / \mathrm{s})$ & $0.53 \pm 0.05$ & $0.51 \pm 0.06$ & 0.791 \\
Atmospheric Pressure (psi) & $14.71 \pm 0.01$ & $14.69 \pm 0.003$ & 0.200 \\
Relative Humidity (\%) & $85.74 \pm 1.25$ & $82.01 \pm 0.86$ & $0.001^{*}$ \\
Wind Turbulence (A-F) & $4.93 \pm 0.27$ & $4.55 \pm 0.23$ & 0.186 \\
Precipitation (mm) & $436.25 \pm 3.45$ & $391.42 \pm 40.28$ & $0.006^{*}$ \\
Sun Radiation $\left(\mathrm{w} / \mathrm{m}^{2}\right)$ & $1582.25 \pm 20.79$ & $1536.25 \pm 25.68$ & $0.028^{*}$ \\
\hline
\end{tabular}

$\mathrm{N}=30$; ${ }^{*}$ Significant at $\mathrm{p}<0.05$.

Findings further revealed that the emission rates varied significantly with distance away from the gas flaring point $(\mathrm{F}=6.196 ; \mathrm{p}=0.004)$. There was also significant variation in the flare temperature $(\mathrm{F}=22.144 ; \mathrm{p}=0.001)$; $\mathrm{NO}_{2}(\mathrm{~F}=8.250 ; \mathrm{p}=0.001), \mathrm{CO}(\mathrm{F}=6.000 ; \mathrm{p}=0.004)$ and VOC $(\mathrm{F}=5.574 ; \mathrm{p}=0.006)$ with distance from the gas flaring point. The variation in the rainwater parameters (Table 4) with distance from the gas flaring also showed that there were significant variations in $\mathrm{pH}(\mathrm{F}=5.594 ; \mathrm{p}=0.006)$; conductivity $(\mathrm{F}=3.670 ; \mathrm{p}=0.028)$; nitrate $(\mathrm{F}=6.359 ; \mathrm{p}=0.003)$; and sulphate $(\mathrm{F}=11.351 ; \mathrm{p}=0.001)$ with distance from the gas flaring point. The variation in the weather parameters with distance from the gas flaring point is shown in Table 5 . It is revealed that only air temperature varied significantly with distance from the gas flaring point $(F=2.597 ; \mathrm{p}=0.049)$. it can be deduced from this result that the flare temperature might have been responsible for the increase in the air temperature in the area close to the gas flaring point and crude oil storage tank. This corroborates with the findings of [20] who reported that gas flaring has been responsible for the elevated temperature of the entire Niger Delta region. Similarly, [21] has reported also that gas flaring has been found to increase both surface and soil temperatures.

The relationships between weather and air quality parameters around the gas flaring point are showed that there was significant positive correlations between flare temperature and atmospheric pressure $(\mathrm{r}=0.610 ; \mathrm{p}<$ $0.05)$; relative humidity $(r=0.452 ; \mathrm{p}<0.05)$; wind turbulence and $(r=0.497 ; \mathrm{p}<0.05)$. Meanwhile, flare temperature had negative relationship with precipitation $(\mathrm{r}=-0.506$; $\mathrm{p}<0.05)$. However, $\mathrm{CO}$ was significantly and positively correlated with air temperature $(r=0.742 ; \mathrm{p}<0.05)$ and negatively with relative humidity $(r=-0.614$; $\mathrm{p}<0.05)$. Furthermore, air temperature had significant positive correlation with VOC $(r=-0.765, \mathrm{p}<0.05)$ while relative humidity had negative correlation with VOC $(\mathrm{r}=-0.617, \mathrm{p}<0.05)$. More importantly, wind speed had significant positive correlation with noise $(r=0.693$; $p<0.05)$.

Result of the relationships between weather parameters and air quality parameters around the crude oil storage tank indicated (Table 6) that the emission rate was positively correlated with relative humidity $(\mathrm{r}=0.462$; $\mathrm{p}<$ $0.05)$; wind turbulence $(r=0.542 ; \mathrm{p}<0.05)$ and negatively correlated with precipitation $(r=-0.562 ; \mathrm{p}<0.05)$. 
Table 4. Analysis of variance of rainwater parameters with distance from gas flaring point.

\begin{tabular}{|c|c|c|c|c|c|c|}
\hline & & Sum of Squares & df & Mean Square & F & Sig. \\
\hline \multirow{3}{*}{$\mathrm{pH}$} & Between Groups & 2.205 & 4 & 0.551 & 3.071 & $0.049^{*}$ \\
\hline & Within Groups & 2.693 & 15 & 0.180 & & \\
\hline & Total & 4.898 & 19 & & & \\
\hline \multirow{3}{*}{ Conductivity } & Between Groups & 2622.065 & 4 & 655.516 & 6.249 & $0.004^{*}$ \\
\hline & Within Groups & 1573.572 & 15 & 104.905 & & \\
\hline & Total & 4195.637 & 19 & & & \\
\hline \multirow{3}{*}{ THC } & Between Groups & 0.000 & 4 & 0.000 & 0.000 & 1.000 \\
\hline & Within Groups & 0.000 & 15 & 0.000 & & \\
\hline & Total & 0.000 & 19 & & & \\
\hline \multirow{3}{*}{ Nitrate } & Between Groups & 1.055 & 4 & 0.264 & 2.648 & 0.075 \\
\hline & Within Groups & 1.494 & 15 & 0.100 & & \\
\hline & Total & 2.548 & 19 & & & \\
\hline \multirow{3}{*}{ Sulphate } & Between Groups & 4.552 & 4 & 1.138 & 5.825 & $0.005^{*}$ \\
\hline & Within Groups & 2.931 & 15 & 0.195 & & \\
\hline & Total & 7.483 & 19 & & & \\
\hline \multirow{3}{*}{$\begin{array}{l}\text { Hydrogen } \\
\text { Carbonate }\end{array}$} & Between Groups & 0.001 & 4 & 0.000 & 3.850 & $0.024^{*}$ \\
\hline & Within Groups & 0.001 & 15 & 0.000 & & \\
\hline & Total & 0.002 & 19 & & & \\
\hline \multirow{3}{*}{ Copper } & Between Groups & 0.000 & 4 & 0.000 & . & . \\
\hline & Within Groups & 0.000 & 15 & 0.000 & & \\
\hline & Total & 0.000 & 19 & & & \\
\hline \multirow{3}{*}{ Chromium } & Between Groups & 2.022 & 4 & 0.506 & 7.972 & $0.001^{*}$ \\
\hline & Within Groups & .951 & 15 & 0.063 & & \\
\hline & Total & 2.974 & 19 & & & \\
\hline
\end{tabular}

$\mathrm{N}=30$; "Significant at $\mathrm{p}<0.05$.

Also, CO was positively correlated with air temperature $(r=0.650, \mathrm{p}<0.05)$ and negatively correlated with relative humidity $(\mathrm{r}=-0.502 ; \mathrm{p}<0.05)$. Furthermore, VOC was positively correlated with relative humidity $(\mathrm{r}=$ $0.475, \mathrm{p}<0.05)$ and wind turbulence $(\mathrm{r}=0.520, \mathrm{p}<0.05)$. Nevertheless, noise had positive relationship with wind speed $(r=0.693, p<0.05)$. Similarly, the relationships between weather parameters and rainwater parameters around gas flaring point (Table 7) indicated that $\mathrm{pH}$ had positive correlations with sun radiation $(\mathrm{r}=$ 0.496; $\mathrm{p}<0.05)$ and nitrate had positive correlation with air temperature $(\mathrm{r}=0.518$; $\mathrm{p}<0.05)$. Furthermore, sulphate had negative correlation with air temperature $(r=-0.477 ; \mathrm{p}<0.05)$ and positive correlation with wind speed $(r=0.556 ; p<0.05)$. Chromium had negative relationship with sun radiation $(r=-0.512 ; p<0.05)$. Figures 2-4 show the emission rate, Particulates, and Volatile Organic compounds (VOCs) away from flare site. The study showed that the concentration of VOC and particulates were high in the supposedly control area which is perceived to be safe for human habitation.

Findings on the relationships between weather and rainwater parameters in crude oil storage tank (Table 8) indicated that $\mathrm{pH}$ had negative correlations with wind speed $(\mathrm{r}=-0.533 ; \mathrm{p}<0.05)$ and atmospheric pressure $(r=-0.450 ; p<0.05)$. Conductivity had positive correlation with atmospheric pressure $(r=0.570 ; p<0.05)$. In addition, nitrate had positive correlation with air temperature $(r=0.566 ; p<0.05)$ and negative correlation with relative humidity ( $r=-0.659$; $\mathrm{p}<0.05$ ). However, sulphate had positive correlation with wind speed $(\mathrm{r}=0.449$; $\mathrm{p}<0.05$ ). Furthermore, the presence of chromium is very evident in the entire study area. This might have 
Table 5. Analysis of variance of weather parameters with distance from gas flaring point.

\begin{tabular}{|c|c|c|c|c|c|c|}
\hline & & $\begin{array}{l}\text { Sum of } \\
\text { Squares }\end{array}$ & df & Mean Square & F & Sig. \\
\hline \multirow{3}{*}{ Air Temperature } & Between Groups & 15.573 & 4 & 3.893 & 2.597 & $0.049^{*}$ \\
\hline & Within Groups & 22.485 & 15 & 1.499 & & \\
\hline & Total & 38.058 & 19 & & & \\
\hline \multirow{3}{*}{ Wind Speed } & Between Groups & 0.197 & 4 & 0.049 & 1.078 & 0.402 \\
\hline & Within Groups & 0.685 & 15 & 0.046 & & \\
\hline & Total & 0.882 & 19 & & & \\
\hline \multirow{3}{*}{ Atmospheric Pressure } & Between Groups & 0.012 & 4 & 0.003 & 1.535 & 0.243 \\
\hline & Within Groups & 0.029 & 15 & 0.002 & & \\
\hline & Total & 0.041 & 19 & & & \\
\hline \multirow{3}{*}{ Relative Humidity } & Between Groups & 195.828 & 4 & 48.957 & 1.857 & 0.171 \\
\hline & Within Groups & 395.500 & 15 & 26.367 & & \\
\hline & Total & 591.328 & 19 & & & \\
\hline \multirow{3}{*}{ Wind Turbulence } & Between Groups & 5.000 & 4 & 1.250 & 0.800 & 0.544 \\
\hline & Within Groups & 23.438 & 15 & 1.563 & & \\
\hline & Total & 28.438 & 19 & & & \\
\hline \multirow{3}{*}{ Precipitation } & Between Groups & $112,139.445$ & 4 & $28,034.861$ & 1.750 & 0.191 \\
\hline & Within Groups & $240,242.085$ & 15 & $16,016.139$ & & \\
\hline & Total & $352,381.530$ & 19 & & & \\
\hline \multirow{3}{*}{ Sun Radiation } & Between Groups & $26,330.000$ & 4 & 6582.500 & 0.716 & 0.594 \\
\hline & Within Groups & $137,893.750$ & 15 & 9192.917 & & \\
\hline & Total & $164,223.750$ & 19 & & & \\
\hline
\end{tabular}

$\mathrm{N}=20 ;{ }^{*}$ Significant at $\mathrm{p}<0.05$.

Table 6. Correlations between weather and air quality parameters in gas flaring point.

\begin{tabular}{|c|c|c|c|c|c|c|c|}
\hline \multirow[b]{2}{*}{ Air Quality } & \multicolumn{7}{|c|}{ Weather Parameters } \\
\hline & $\begin{array}{c}\text { Air } \\
\text { Temperature }\end{array}$ & $\begin{array}{l}\text { Wind } \\
\text { Speed }\end{array}$ & $\begin{array}{l}\text { Atmospheric } \\
\text { Pressure }\end{array}$ & $\begin{array}{l}\text { Relative } \\
\text { Humidity }\end{array}$ & $\begin{array}{c}\text { Wind } \\
\text { Turbulence }\end{array}$ & Precipitation & $\begin{array}{c}\text { Sun } \\
\text { Radiation }\end{array}$ \\
\hline Emission rate & -0.277 & 0.359 & 0.053 & 0.367 & 0.378 & -0.386 & 0.305 \\
\hline $\begin{array}{c}\text { Flare } \\
\text { Temperature }\end{array}$ & -0.366 & 0.346 & $0.610^{*}$ & $0.452^{*}$ & $0.497^{*}$ & $-0.506^{*}$ & 0.322 \\
\hline $\mathrm{NO}_{2}$ & -0.312 & 0.175 & 0.320 & 0.375 & 0.257 & -0.345 & 0.104 \\
\hline $\mathrm{CO}$ & $0.742^{*}$ & -0.336 & -0.225 & $-0.614^{*}$ & -0.288 & 0.361 & 0.050 \\
\hline SPM & 0.098 & 0.189 & -0.035 & -0.196 & -0.156 & -0.283 & -0.232 \\
\hline VOC & $0.765^{*}$ & -0.303 & -0.022 & $-0.617^{*}$ & -0.225 & $0.444^{*}$ & -0.064 \\
\hline Noise & -0.247 & $0.693^{*}$ & 0.025 & -0.085 & -0.227 & -0.084 & -0.061 \\
\hline
\end{tabular}

$\mathrm{N}=20$; 'Significant at $\mathrm{p}<0.05$.

influence in the chromium level in the rain water. Wind speed fell within $0.35 \mathrm{~m} / \mathrm{s}-0.63 \mathrm{~m} / \mathrm{s}$. This suggests that the wind speed in the entire study area is calm which suggest accumulation of pollutants at the ground level. [22]-[25] reported that stagnant weather conditions with low wind speed of $>2 \mathrm{~m} / \mathrm{s}$ contributes to accumulation 
Table 7. Correlations between weather and rainwater parameters in gas flaring point.

\begin{tabular}{cccccccc}
\hline & \multicolumn{7}{c}{ Weather Parameters } \\
$\begin{array}{c}\text { Rainwater } \\
\text { Parameters }\end{array}$ & \begin{tabular}{c} 
Air \\
\cline { 2 - 8 }
\end{tabular} & $\begin{array}{c}\text { Wind } \\
\text { Temperature }\end{array}$ & $\begin{array}{c}\text { Atmospheric } \\
\text { Pressure }\end{array}$ & $\begin{array}{c}\text { Relative } \\
\text { Humidity }\end{array}$ & $\begin{array}{c}\text { Wind } \\
\text { Turbulence }\end{array}$ & Precipitation & $\begin{array}{c}\text { Sun } \\
\text { Radiation }\end{array}$ \\
\hline $\mathrm{pH}$ & 0.438 & -0.248 & 0.179 & -0.210 & 0.286 & -0.360 & $0.496^{*}$ \\
Conductivity & -0.332 & 0.257 & -0.090 & 0.315 & -0.044 & -0.152 & -0.099 \\
Nitrate & $0.518^{*}$ & -0.008 & 0.191 & -0.328 & -0.154 & -0.046 & 0.213 \\
Sulphate & $-0.477^{*}$ & $0.556^{*}$ & 0.125 & 0.392 & 0.142 & -0.170 & 0.006 \\
$\begin{array}{c}\text { Hydrogen } \\
\text { Carbonate }\end{array}$ & -0.306 & -0.040 & 0.043 & 0.153 & 0.216 & -0.138 & -0.139 \\
Chromium & 0.093 & -0.218 & -0.039 & -0.111 & -0.216 & -0.011 & $-0.512^{*}$ \\
\hline
\end{tabular}

$\mathrm{N}=20$; ${ }^{*}$ Significant at $\mathrm{p}<0.05$.

Table 8. Correlations between weather and rainwater parameters in crude oil storage tank.

\begin{tabular}{cccccccc}
\hline & \multicolumn{7}{c}{ Weather Parameters } \\
Rainwater \\
\cline { 2 - 3 } & $\begin{array}{c}\text { Air } \\
\text { Temperature }\end{array}$ & $\begin{array}{c}\text { Wind } \\
\text { Speed }\end{array}$ & $\begin{array}{c}\text { Atmospheric } \\
\text { Pressure }\end{array}$ & $\begin{array}{c}\text { Relative } \\
\text { Humidity }\end{array}$ & $\begin{array}{c}\text { Wind } \\
\text { Turbulence }\end{array}$ & Precipitation & $\begin{array}{c}\text { Sun } \\
\text { Radiation }\end{array}$ \\
\hline $\mathrm{pH}$ & 0.114 & $-0.533^{*}$ & $-0.450^{*}$ & 0.002 & 0.000 & -0.042 & 0.245 \\
Conductivity & -0.110 & 0.033 & $0.570^{*}$ & 0.113 & 0.224 & -0.075 & -0.037 \\
Nitrate & $0.566^{*}$ & 0.115 & -0.061 & $-0.659^{*}$ & -0.001 & 0.346 & 0.024 \\
Sulphate & -0.332 & $0.449^{*}$ & 0.430 & 0.152 & 0.132 & -0.148 & -0.199 \\
$\begin{array}{c}\text { Hydrogen } \\
\text { Carbonate }\end{array}$ & -0.169 & 0.291 & -0.215 & 0.047 & -0.029 & -0.177 & -0.118 \\
Chromium & 0.078 & -0.137 & 0.158 & -0.033 & -0.165 & 0.223 & -0.277 \\
\hline
\end{tabular}

$\mathrm{N}=20$; 'Significant at $\mathrm{p}<0.05$.

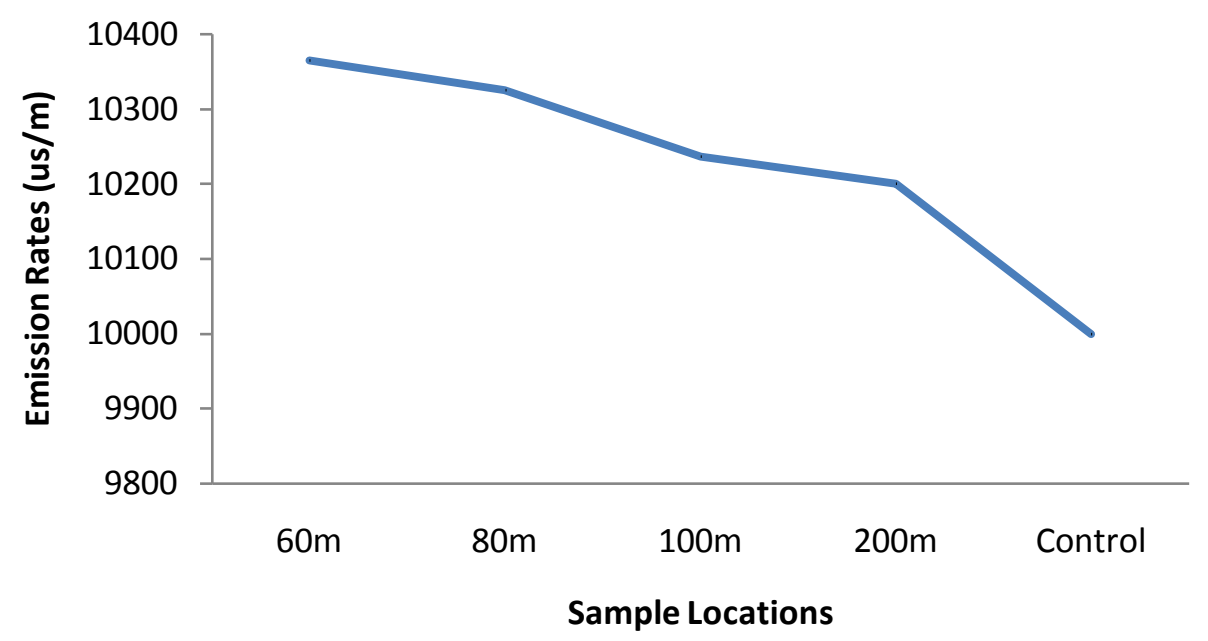

Figure 2. Emission rate from gas flaring point.

of pollutants at ground level. By implication, this makes the accumulation of the air and rainwater pollutants to be deposited heavily around the sources of the pollutants (Gas flaring point and Crude oil storage tank. 


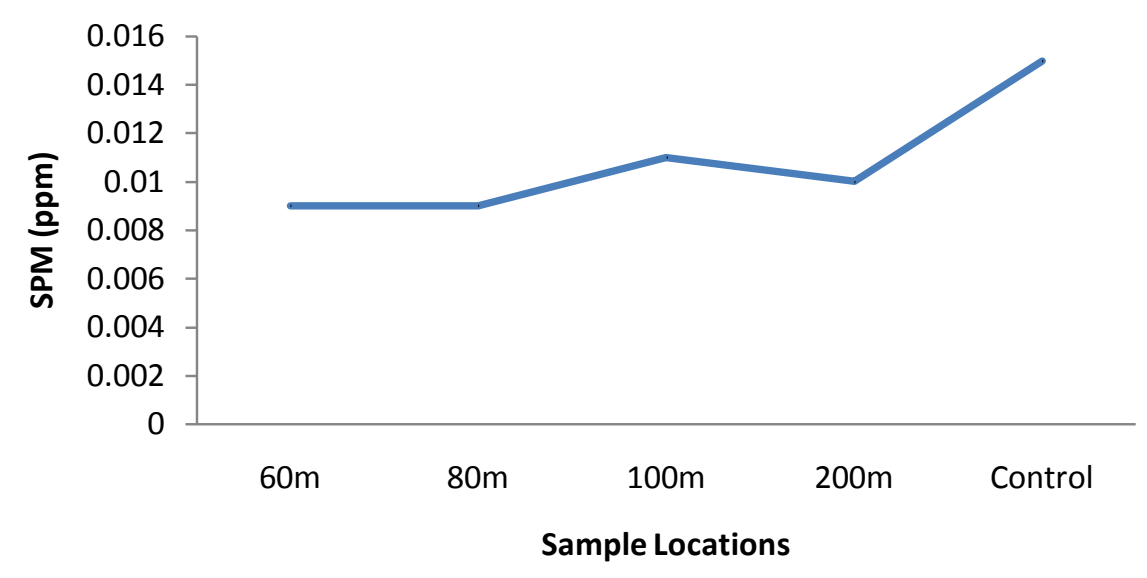

Figure 3. Concentration of solid particulate matters from gas flaring point.

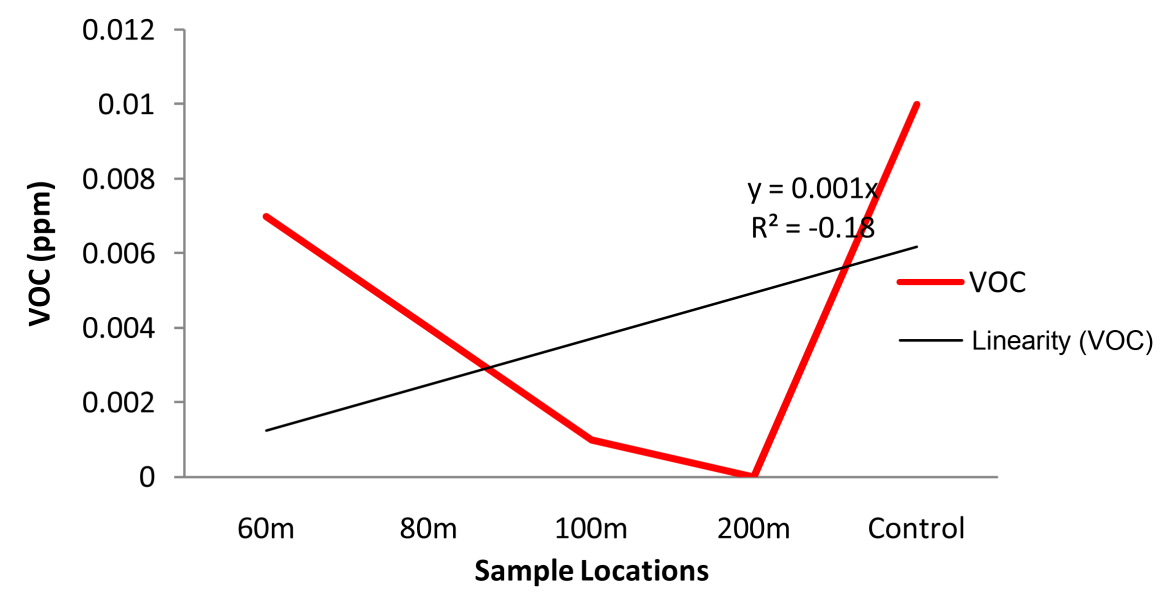

Figure 4. Trend line and concentration of volatile organic compounds from gas flaring point.

\section{Conclusion}

This study has shown that the air and rainfall water quality are compromised as a result of emissions from gas flare and crude oil storage tanks in Bonny. Specifically, the turbulent generated from the flare instigated the initial dispersion of the pollutants which were transported to the residential areas found downwind of the industrial area in the island. This compromised the air quality of the residential areas which spelled dome for the island residents. However, the moderating influence of the sea breeze from the Gulf of Guinea may have influenced the variations in temperature around the residential areas causing a cooling effect which favours stagnation of atmospheric pollutants. These have serious implications for the health of residents and the conditions of the environment at large.

\section{References}

[1] Ismail, O.S. and Umukoro, G.E. (2012) Global Impact of Gas Flaring. Energy and Power Engineering, 4, $290-302$. http://dx.doi.org/10.4236/epe.2012.44039

[2] Ite, A.E. and Ibok, U.J. (2012) Gas Flaring and Venting Associated with Petroleum Exploration and Production in the Nigeria's Niger Delta. American Journal of Environmental Protection, 1, 70-77.

[3] Weli, V.E. and Kobah, E. (2014) The Air Quality Implications of the SPDC-Bomu Manifold Fire Explosion in K-Dere, Gokana LGA of Rivers State, Nigeria. Maxwell Sciences. Research Journal of Environmental and Earth Sciences, 6, 769-777.

[4] Weli, V.E. and Arokoyu, S.B. (2014) Impact of SPDC-Bomu Manifold Oil Pipe Explosion Fire on Crop Yield and 
Farm Income in Gokana LGA, Rivers State. Maxwell Science Research Journal of Applied Sciences, Engineering and Technology, 7, 2851-2857.

[5] United Nations Development Programme (UNDP) (2006) Niger Delta Human Development Report. United Nations Development Programme, UN House, Plot 617/618, Diplomatic Zone, Central Area District, Abuja.

[6] Somboon, W. (1997) Acid and Some Heavy Metal Composition of Rain in Bangkok, Thailand: Research in the Faculty of Science, King Mongkut Institute of Technology. Thomburi Bangkok, Thailand.

[7] Oluwole, A.F., Olaniyi, H.B., Akeredolu, F.A., Ogunsola, O.J. and Obioh, I.B. (1996) Impact of the Petroleum Industry on Air Quality in Nigeria. 8th Biennial International Seminar on the Petroleum Industry and the Nigerian Environment, Port Harcourt, 17-21.

[8] Elvidge, C., Ziskin, D., Baugh, K., Tuttle, B., Ghosh, T., Pack, D. and Zhizhin, M. (2009) A Fifteen Year Record of Global Natural Gas Flaring Derived from Satellite Data. Energies, 2, 595-622. http://dx.doi.org/10.3390/en20300595

[9] Famuyiwa, B.A. (1998) Seabed Survey of the Impact of Oil Based Drilling Fluid System on Offshore Environment. 9th International Conference on the Petroleum Industry and the Nigerian Environment, Abuja, 5-7 November 1998, 461-489.

[10] Olobaniyi, S.B. and Efe, S.I. (2007) Comparative Assessment of Rainwater and Groundwater Quality in an Oil Producing Area of Nigeria: Environmental and Health Implications. Journal of Environmental Health Research, 6, 111118.

[11] Okoye, A.C., Oluyemi, E.A., Oladikpo, A.A. and Ezeonu, F.C. (2011) Physicochemical Analysis and Trace Metal Levels of Rainwater for Environmental Pollution Monitoring in Ile-Ife, South-Western Nigeria. Journal of International Environmental Application \& Science, 6, 326-331.

[12] Ikporukpo, C. (1998) Environmental Impact Assessment and Human Concern in the Petroleum Industry: Nigeria's Experience. 9th International Conference on the Petroleum Industry and the Nigerian Environment, Abuja, 5-7 November 1998, 766-782

[13] Dung, E., Bombom, L. and Agusomu, T. (2008) The Effects of Gas Flaring on Crops in the Niger Delta, Nigeria. GeoJournal, 73, 297-305. http://dx.doi.org/10.1007/s10708-008-9207-z

[14] Sojinu, S.O., Wang, J. and Sonibere, O. (2009) Polycyclic Aromatic Hydrocarbons in Sediments and Soils from Oil Exploration Areas of the Niger Delta, Nigeria. Journal of Hazardous Materials, 174, 641-647. http://dx.doi.org/10.1016/j.jhazmat.2009.09.099

[15] Alakpodia, I.J. (2000) Soil Characteristics under Gas Flares in the Niger Delta, Southern Nigeria. Geo-Studies Forum, 1, 1-9.

[16] Odjugo, P.O. (2007) The Impact of Climate Change on Water Resources, Global and Regional Analysis. The Indonesian Journal of Geography, 39, 23-41.

[17] SPDC (2006) Annual Report on Environmental Monitoring of Gaseous Emissions from SPDC-East Production Facilities Bonny Oil and Gas Terminal. SPDC Bulletin.

[18] Sonibare, J.A. and Akeredolu, F.A. (2004) A Theoretical Prediction of Non-Methane Gaseous Emissions from Natural Gas Combustion. Energy Policy, 32, 1653-1665. http://dx.doi.org/10.1016/j.enpol.2004.02.008

[19] Ajugwo, A.O. (2013) Negative Effects of Gas Flaring: The Nigerian Experience. Journal of Environment Pollution and Human Health, 1, 6-8.

[20] Aghalino, S.O. (2009) Gas Flaring, Environmental Pollution and Abatement Measures in Nigeria, 1969-2001. Journal of Sustainable Development in Africa, 11, 219-238.

[21] Odjugo, P.A.O. and Osemwenkhae, E.J. (2009) Natural Gas Flaring Affects Microclimate and Reduces Maize (Zea mays) Yield. International Journal of Agriculture \& Biology, 11, 408-412.

[22] Hopke, P.K., Ito, K., Mar, T., Henry, R.T. (2006) Particulate Matter Source Apportionment and Health Effects: InterComparison of Source Apportionment Results. Journal of Exposure Science and Environmental Epidemiology, 16, 275-286. http://dx.doi.org/10.1038/sj.jea.7500458

[23] Utang, P.B. and Peterside, K.S. (2011) Spatio-Temporal Variations in Urban Vehicular Emission in Port Harcourt City, Nigeria. Ethiopian Journal of Environmental Studies and Management, 4, 38-51. http://dx.doi.org/10.4314/ejesm.v4i2.5

[24] Weli, V.E. (2014) Atmospheric Concentration of Particulates and Its Implications for Respiratory Health Hazard Management in Port Harcourt Metropolis, Nigeria. Journal of Civil and Environmental Research, 6, 11-17.

[25] Weli, V.E. and Adekunle, O. (2014) Meteorological Conditions in the Vicinity of Landfill and Its Implications for Atmospheric Pollutant Stagnation in Rumuolumeni, Port Harcourt, Nigeria. Journal of Natural Sciences Research, 4, 5164. 